\title{
CONFERENCE REPORT: INTERNATIONAL CONFERENCE "Child FACING Mediation" (WROCLAW, 10 MAY 2013)
}

\author{
MAGDALENA ABU GHOLEH*
}

On 10 May 2013, the Faculty of Law, Administration and Economics at the University of Wroclaw hosted an international scientific conference titled "Child facing mediation". The conference was held under the honorary patronage of Human Rights Defender prof. dr hab. Irena Lipowicz, and the Children's Rights Ombudsman Marek Michalak. It was the first conference in a series titled "Practical aspects of the use of mediation in the courts, the prosecutor's office and public administration" under the honorary patronage of the Minister of Justice and the Prosecutor General.

The conference was organized thanks to the joint efforts of the Institute of Administrative Sciences and Interdisciplinary Student Study Circle ISKRA from the Faculty of Law, Administration and Economics, University of Wrocław, the Trade Union of Prosecutors and Workers of the Polish Public Prosecutorial Service, and the Lower Silesia Mediation Center. The organizing committee consisted of dr Magdalena Tabernacka, dr Karolina Kremens and Barbara Zyzda from the Faculty of Law, Administration and Economics, district court judge and social counselor for the Children's Rights Ombudsman Agnieszka Rękas, Magdalena Abramowicz, and Tomasz Salwa, a prosecutor from the district prosecutorial service.

The main objective of the conference was to present and analyze the legal and social position of a child as a participant in mediation, and

DOI: $10.1515 /$ wrlae-2015-0008

* Law and Administration student at Faculty of Law, Administration and Economics of University of Wroclaw, member of Interdisciplinary Student Study Circle ISKRA;

mabugholeh@gmail.com. 
psychological aspects of mediation involving children as both participants and observers - in conflicts in family, civil and criminal matters. The following issues were raised:

- psychological and legal position of a child as an observer of mediation in a conflict between adults - in family matters, but also in civil disputes and disputes arising out of criminal offenses;

- the position of a child as a participant in peer mediation during conflicts in educational institutions;

- the position of a child in mediation concerning juvenile offenders and juvenile victims.

The premise of the conference was to combine the findings of science and practical experience. The organizers are of the opinion that this was done, as the event was attended by both academics and practitioners. The conference was an opportunity to compare doctrine with the experiences of judges, prosecutors, mediators, psychiatrists and psychologists specialized in child psychology, and pedagogues. Over 300 attendees participates at the conference.

The intention of the conference's organizers was to promote the institution of mediation, but also to formulate guidelines that would allow for the greater use of mediation within the current law. The practice of courts and public institutions shows that mediation is still used insufficiently. The existence of a number of legal, organizational and social barriers can be observed. Awareness of these limitations is essential to adapt particular legal and institutional solutions to the specificity of existing conditions, particularly when it comes to an areas as sensitive as the interests of a child.

Conference participants were welcomed by prof. dr. hab. Wieslaw Miemiec, Deputy Dean of the Faculty of Law, Administration and Economics, University of Wroclaw. The conference was then opened by the Ombudsman for Children, Marek Michalak. His remarks concerned the issue of communication involving the participation of children, parents and employees of educational institutions.

A surprise prepared by the organizers in order to foster a good atmosphere for the meeting was the speech given by Iwona Kucharzak - Dziuda, who presented her interpretation of the text entitled "The Cat".

The proceedings of the conference were held in three sessions.

The first one was entitled "Peer mediation - the school and conflict". It discussed potential sources of conflicts involving children in a peer environment and in educational institutions. Alternative methods of resolving disputes arising in connection with such conflicts were also presented. The session was moderated by dr Maciej Lis, Regional Representative of the Human Rights Defender in Wroclaw.

Agnieszka Rękas, district court judge, Social Advisor to the Children's Rights Ombudsman, and member of the Social Affairs Council of Alternative Methods for Solving Conflict and Dispute Resolution at the Ministry of Justice, gave a presentation detailing the course and implementation of the program "Peer mediation in school as a tenet of aggression and social maladjustment". This program was carried out in school year 2011/2012, at 11 selected junior high schools located within the territorial district of the District Court in Lublin. The justice observed that 
children's contacts within their peer group and during everyday situations at school are of great importance for their future conflict resolution skills in adulthood. This is how children learn to reach agreement in the future without violence, to use force - often physical and psychological violence to impose their will on others instead, or to succumb to pressure exerted by others, resulting in a deepening of conflict. In Agnieszka Rękas's opinion, peer mediations are lessons in the skill of independent conflict resolution on terms favorable to both parties. Teaching mediation in schools is therefore of particular importance, because school should also prepare pupils for life in society.

A continuation of the activities carried out by the Lublin judges and teachers may consist be the program presented by mediator and psychologist Magdalena Abramowicz together with prosecutors from the district public prosecutor's office, Tomasz Salwa and Adam Handke. Their remarks were presented in a speech titled "Safe functioning of children in the peer environment - threats and ways to counter them in the activities of educational institutions." Magdalena Abramowicz also presented the results of research on mediation carried out in Wrocław schools. They show clearly that the institution of mediation is practically unknown among adolescents. The aim of the aforementioned program is the integration of the activities of mediators, prosecutors and other institutions to raise awareness of the threats which children encounter in their environments. This particularly concerns the development of competence and legal awareness of pedagogues and young people, which should include practical conflict resolution skills.

Experiences in implementing a similar program for mediation were presented by dr Bartosz Olszewski in his paper titled "Alternative dispute resolution in school - practical experience".

A particularly engaging event was the presentation by justice Anna Maria Wesołowska titled "New threats: grooming, cyberbullying, premature sexual initiation, the use of children in parents' conflicts in family matters, and ways educational institutions can react".

The first session was concluded with a presentation by Jacek Skała, prosecutor from the district public prosecutorial service, who spoke from the perspective of a prosecutor and addressed the issue of mediation as a method of resolving disputes involving children.

The second session was entitled "The child in disputes resolved in a conflict before judicial authorities". It was devoted to analyzing issues involving children in conflicts resolved before a court - in court procedures, mediation pending in court proceedings, and preparatory proceedings. The speeches gave attendees an opportunity to compare Polish solutions with ones applied aboard. The session was moderated by dr Karolina Kremens.

Judge Lutz Bode, in his speech titled "The role of the child in mediation", presented the German experience regarding the participation of children in judicial proceedings. Next, justice Christoph Pietryka presented remarks titled "Is the presence of a child during mediation desirable?" during which he spoke about experiences involving children in divorce proceedings and custodial cases. 
The speech "The child in mediation - family conflicts in situations of divorce and separation" by mediator Heiner Krabbe was translated and copresented by Agnieszka Beckschulte-Sibilak. It took the shape of interaction with conference participants sitting in the audience. It was explained and demonstrated that during the conflicts associated with divorce, the parties think only about themselves. Mediation is therefore a tool to ensure that parents and children can work out the guidelines of their lives together in the future.

Aleksandra Rembiasz, justice of the district court in Kłodzko, presented a paper titled "Questioning of a juvenile witness in a friendly interview room during court proceedings" in which she discussed experiences in conducting hearings on child-friendly terms. Her determination and passion led to the creation of such a room in the district court in Kłodzko. In her opinion, it is the only effective and recommendable method for the participation of children in hearings.

Dorota Trautman, justice of the district court in Warsaw, referred to the Polish experience in her lecture titled "Parental disputes in cases relating to child custody and the perspective of mediation". As the speaker observed, disputes between parents concern mostly determining the child's place of residence, and also on the reduction or even deprivation of parental authority of one of the parents at the request of the other. Disputes frequently involve the issue of contacts with the child. According to justice Trautman, in disputes arising as a result of disagreement between the parents, but not as a result of obvious problems in the performance of parental duties, the court should seek to determine the cause of the lack of cooperation between the parents and to attempt to reach a mutual understanding before issuing a judgment. There is room for the action of a mediator here.

Dr Agata Gójska of Warsaw University presented the results of her research and analysis in remarks titled "The issue of the efficiency of divorce mediation in the Warsaw District Court".

The third session was titled "The legal, social and psychological position of the child in mediation." Its purpose was to present psychological, legal and social issues related to mediation involving children. The session was moderated by dr Magdalena Tabernacka.

"Areas of uncertainty in family mediation - the practice of applying the law in settlements pertaining to the interests of the child" was the subject of the speech given by the notary and mediator Barbara Jadwiga Pawlak. Ms Pawlak remarked that deficiencies in the legal preparation of mediators may be the cause of very undesirable consequences associated with the mediation, such as inability to reach a settlement and negative psychological impact on the parties to mediation when they cannot implement a finished agreement.

Psychiatrist Magdalena Koterwa-Kniaź discussed her paper "The psyche of the child in terms of conflict", in which she raised the issue of mediation as a remedy for family conflicts. She also turned her attention to the typical reactions of a child to family conflict, such as somatic reactions or compensatory reactions in the sphere of social functioning, like seeking "appreciation" in criminal groups. The consequences of unresolved conflicts 
concerning families analyzed by Ms Koterwa-Kniaź include post-traumatic stress disorder, depression and addictions as a way of releasing the tension from conflict in the family. She also observed that behavior in the family setting has a significant impact on both the social functioning and the health of family members, although this is not always obvious. Therefore, the mental health of children should be closely monitored.

A joint presentation by dr Magdalena Tabernacka and dr Karolina Kremens of the University of Wroclaw, titled "Mediation and statutory prohibition of corporeal punishment excluding non-statutory justifications of punishment of children by parents" addressed cultural conditions of the use of physical violence against children and the consequences of regulations prohibiting the application of this type of discipline.

The conference was concluded with the lecture "Mediation in cases of juvenile perpetrators of criminal acts and its consequences in the legal and psychological spheres". The speech was the result of research conducted by dr Katarzyna Liżyńska of the University of Wroclaw and dr Justyna Żylińska of the Helena Chodkowska University of Management and Law in Warsaw. The authors drew attention to the educational objective of mediation in juvenile cases, and realization of the harm caused to the victim by the necessity of compensation for such harm.

Mediation is one of the elements of the practice of public authorities which contributes to the development of civil society and the functioning of an open society - a society in which stigma and social exclusion are not phenomena which serve to permanently impair its members. Mediation as an institution and as a tool for starting dialogue in situations where the parties to the conflict have the chance to reach an agreement, yet are unable to do so on their own, becomes not only a privilege but the duty of public authorities pursuing the idea of the democratic, law-governed state in Poland. Therefore, the organizers made an attempt to compare the assumptions of the model institution of mediation with the experience of practitioners across a broad scope of public authorities, as well as to contrast the practices and legal conditions for mediation in Poland to those of other countries. 